\title{
Holistic Approach in Cases of İrritable Bowel Syndrome
}

\author{
Hayriye Alp \\ Necmettin Erbakan University, GETAT CENTER, Konya, Turkey.
}

Corresponding Author: Hayriye Alp, Necmettin Erbakan University, GETAT CENTER, Konya, Turkey.

Received date: June 01, 2021; Accepted date: June 05, 2021; Published date: June 15, 2021

Citation: Hayriye Alp (2021) Holistic Approach in Cases of İritable Bowel Syndrome. J. Gastroenterology Pancreatology and Hepatobilary Disorders. 5(3) DOI: 10.31579/2641-5194/034

Copyright: (C) 2021, Hayriye Alp, This is an open access article distributed under the Creative Commons Attribution License, which permits unrestricted use, distribution, and reproduction in any medium, provided the original work is properly cited.

\begin{abstract}
Inflammatory Bowel Diseases (IBD), which starts with intestinal inflammation and mucosal tissue damage, progresses with an impaired immune response, causes intestinal and extraintestinal symptoms, whose etiology is unknown, and which systemic chronic diseases that significantly affect their quality of life. Diseases. The mainstay of treatment in IBD is the elimination of symptoms, remission is achieved by mucosal healing, maintenance of remission and prevention of recurrence. The aim of treatment in IBD is to improve clinical laboratory, mucosal and quality of life. Conventional treatment for the disease.It is not sufficient to correct related complications. Therefore, new treatment modalities should be initiated as early as possible.

From a modern medical perspective, inflammatory bowel diseases are nowadays often referred to as autoimmune diseases.It is accepted. To find the right individual remedy, inflamed bowel It is also important to look at possible causes of the disease. Because In the Regulatory Medicine approach, holistic healing is by eliminating the causes, not by suppressing or treating the symptoms best done by removing.
\end{abstract}

Key words; inflammatory bowel diseases (1bd, regulatory medicine,gut)

\section{Introduction}

Inflammatory Bowel Diseases (IBD), which starts with intestinal inflammation and mucosal tissue damage, progresses with an impaired immune response, causes intestinal and extraintestinal symptoms, whose etiology is unknown, and which systemic chronic diseases that significantly affect their quality of life diseases [1, 2, 3].

The pathogenesis of IBD is multifactorial and still not fully explained [1]. The mechanism of tissue damage and better understanding of molecular mediators in the pathogenesis of the disease genetic, infectious, immunological and inflammatory showed that factors are important (2). inflammatory bowel disease abdominal pain, diarrhea, stool blood, weight loss, and even chronic fatigue. Diarrhea may be bloody, sticky, or both. Inflammatory Bowel Disease (IBD); It is a common chronic gastrointestinal system that starts with intestinal inflammation and mucosal tissue damage, progresses with an impaired immune response, causing intestinal and extraintestinal symptoms disease [4].

The mainstay of treatment in IBD is the elimination of symptoms, Remission is achieved by mucosal healing, maintenance of remission and prevention of recurrence.The aim of treatment in IBD is to improve clinical laboratory, mucosal and quality of life. Conventional treatment for the disease.It is not sufficient to correct related complications. Therefore, new treatment modalities should be initiated as early as possible.
From a modern medical perspective, inflammatory bowel diseases are nowadays often referred to as autoimmune diseases.It is accepted. This means: some of the immune system parts of it to the body's own tissue, in this case the gut attacks the mucosa/intestinal wall.

Many autoimmune diseases may occur due to the deterioration of the intestinal wall integrity. In this study, we opened the changes observed when we added the holistic approaches followed in cases with impaired intestinal integrity to the conventional treatment of the patient.

\section{Case1}

43Years old female.there are diabetes mellitus, hepatostetosis ,kolesistectomy(2003) operation in her history .she uses diaformin and levothyron $2 * 1$.her mother diabetes,her father cancer. $\mathrm{Hb}$ 11,3mg/dl,WBC 12,3Ig E 9,8.TSH 2,43mu/l.Glucose 95, ürea 26, creat $0.5 \mathrm{mg} / \mathrm{dl}, \mathrm{SGOT} 17, \mathrm{SGPT} 16 \mathrm{U} / \mathrm{L}$

Livex tb $2 * 1$ (Silimarin+dandelion),probiotic, olive leaf, and homeopathic helidonia c200, chel majus c30 $2 * 1$ was started.

\section{Case 2}

49 Years old female. Konstipation,distansion ,pain for 7-8 years.ürea 17,creat $0,17, \mathrm{Na} 147, \mathrm{~K} 4,5 \mathrm{Mg} 2,18$, SGOT 9,6,SGPT 9,6, TSH 4,41 .Okubaca 30 , nux vomica c30 $2 * 1$ was started.

Case 342 years old female.obesity BMI 30,9, Long 170,kg 89,2,adipose tissue \%40.3 BMR 1626, Hashimato tiroiditis;TSH 1,28,HbA1c 5,5 
glucose 85, CA 9,74, creat 0,84, SGOT 14,4, SGPT 37, Ürea 2,7 B12 358, $\operatorname{Diet}(1400$ cal),acupunctrue and homeopathic graphites c30, thyroiodinum c30 was started.

\section{Case 3}

35 Years old female obesity and diabetes mellitus. Glucose 172,cholesterol 141, TG 131, HbA1c 11,1, B12 781, Mg 2,42, D vit 14,82, $\mathrm{Hb}$ 12.acupuncture and $\operatorname{diet}(1400 \mathrm{cal})$, livex tb $2 * 1$, olive leaf, alfa alfa was started.

\section{Case 4}

31 Years old female.obesity, insüline rezistanse and cervical disc hernia pain VAS 9, (Neuropathic pain ) timoma and brain bleeding operation in her history.glucose 85, Na 142, K 4,5 Ca 9,78, TG 167, Total cholest 267, d vit 22,43, GGT 59. Metil cobalamin and magnesium glisinat was started. Acupuncture is made.

\section{Case 5}

40 Years old male. İrritable gut syndrome for 2013.acupuncture and gaps diet are given. Phosfor c200, merc suhubic c200, acid carb d6 was started.

\section{Case 6}

60 years old female gastritis,hypertansion and cervikal disc hernia. Cholesistectomy, TAH+BSO, Eye operation in her history. Hypericum c200, rhus tox c30(hernia) okubaka c30 (gastritis), magnesium glisinat was started.

\section{Case 7}

29 years old female.fibromyalgia, systemic lupus erytematozis and gluten intoleras.VAS 8. Glukose 131,Mg 2,19, ferritine 6,3, B12 480, d vit 23,6 gaps diet, wet-cupping and homeopathic rhus tox c30 hyper c 30 passiflora c30 $2 * 1 \mathrm{~d}$ vitamine and methy cobalamin $1 * 1$ was started. VAS $2: 3$

\section{Case 8}

42 Years old male. Diare with blood 30 times in day. Cholesterol 242, TG 220,ÜREA 26, CREAT 0,8, Hb 15,Ferrum 46, ferim bindin capacite 296,GAPS diet and Ozone therapy infused. In 3.session 4 times in day diare.

\section{Case 9}

44 years old male. $120 \mathrm{~kg}, 176 \mathrm{~cm}$,hepatosteatozis, glukose 75 , ürea 26,7 , creat 26, $\mathrm{Hb} 16 . \operatorname{diet}(1400 \mathrm{cal})$ acupuncture and livex tb $2 * 1$ (silimarin+dandelion+Thistle) was started.

\section{Case 10}

38 Years old female .obesity.BMI 36.5,KG 97,Long $163 \mathrm{~cm}$,creat 0,92, TSH 0,1, t3 7,6,Hb13,T4 1,41,diet, and acupuncture started. BMI 234.5 KG 2 91,6

\section{Case 11}

48 Years old female irritable gut syndrome, fibromyalgia, and breast cancer,cesearian(2003), mastectomy(2018), hysterectomy(2019), cist hidatic operation(2019) in her history.she use tamoxifen . GAPS Diet ,5 seans ozone therapy and homeopathic phytolacca c200 $2 * 1$ was started.patient was relaxed.

\section{Result}

The Regulatory Medicine approach and holistic measures can often alleviate the symptoms of inflammatory bowel disease and prolong the symptom-free phases so that it is always they must be used together. In some cases, patients may be permanently injured, especially in combination .Became asymptomatic, which can be defined as cured $[6$, 7].

To find the right individual remedy, inflamed bowel It is also important to look at possible causes of the disease. Because In the Regulatory Medicine approach, holistic healing is by eliminating the causes, not by suppressing or treating the symptoms best done by removing.

\section{Discussion}

In a 2017 study (5), the gut-brain joint was mentioned in connection with inflammatory bowel disease. Intestine-brain axis, brain and digestive systemis the link between Therefore, both body parts where they can exchange information and at the same time .There is a possibility of communication that can be "infected". In this way, mental While stress causes gastrointestinal problems and intestinal flora disorders, conversely, inflammatory processes in the gut can affect the brain and cause depression there.

Antibiotics $(\mathrm{AB})$ are still prescribed. However, antibiotics change the environment in the intestine very negatively. They can destroy the intestinal flora and, especially in children, they can also damage the intestinal mucosa in adults as well as in adults.

If the intestinal mucosa becomes partially permeable, it is called leaky gut syndrome. Here is the gut

The cavities in the mucosa allow incompletely digested proteins to enter the bloodstream and reach the lymphatic system. There, initially with small foci of inflammation harmful substances that trigger some type of allergic reaction (the so-called are known as antigens $(6,7)$.

Tooth decay, indirectly the development of autoimmune diseases (eg, when dental fillings containing mercury are used and the subject is exposed to mercury) (8).

A 2015 study showed in this context: The higher a person's exposure to mercury, the more blood they have. The more autoantibodies circulate and the risk of autoimmune disease as high as it gets. This is why you should avoid amalgam (mercury-containing material for fillings) and protect yourself from mercury, especially if you already have inflammatory bowel disease or have a family history of it.

Vitamin D deficiency is now common in chronic diseases, including chronic inflammatory bowel disease found. A 2013 Danish study compared 182 patients with Crohn's to 62 healthy patients. The healthy group clearly differed from the patients had higher levels of vitamin D. Also the patient the stronger the symptoms in the group, the lower the vitamin D level.

It can also be seen that it is lower [9]

IBD patients often suffer from vitamin C deficiency (hair loss).

Hair loss, dry hair, brittle nails, inflammation of the gums, etc.) $(6,10)$. One in 1990

The study also showed that vitamin C ( 1 g per day) improved the function of T cells (11). Especially in autoimmune diseases, the balance of various $\mathrm{T}$ cells is disturbed, thus $\mathrm{C}$ may have a regulating effect. Therefore, if you have inflammatory bowel disease, vitamin and to determine your mineral 
values and find the missing items. It is very important to take it with food supplements [6].

Thanks to curcumin, positive effects have also been found in human studies: For example, in a small study from 2005, 1,100 mg of curcumin per day for the first month in ulcerative colitis patients and after taking 1,650 , the disease exacerbation improved within two months. mg curcumin in the second month [12].

Resveratrol is a powerful antioxidant and anti-inflammatory herb.

Is the item. In 2010, in rats, resveratrol not only ameliorated intestinal inflammation, but also increased colonic inflammation.

It has also been shown to reduce the risk of cancer. Without resveratrol, $80 \%$ of rats had long-term symptoms due to intestinal inflammation developed colon cancer in the term; only $20 \%$ with resveratrol was [13].

To regulate these disorders, probiotics (beneficial bacterial strains found in healthy intestinal flora) are commonly used.

Recommendations for its use, however, for chronic inflammatory bowel not possible in case of illness. Because it's so different

There are many different probiotic preparations with compositions and each bacterial strain or combination of bacteria.

It may work quite differently - possibly depending on the patient's current condition and the existing gut flora [6]. Zeolite is a mineral soil that detoxifies, regenerates and is friendly to intestinal flora. Due to the porous structure of zeolite crystals, mineral soil also absorbs excess water. absorbs and therefore is effective against diarrhea.

A study conducted by the Medical University of Graz in 2015.

From the study [14] it was found that after 12 weeks $1.85 \mathrm{~g}$ of zeolite per day could increase the permeability of the intestinal barrier and therefore shown to have a mild anti-inflammatory effect. A study conducted in 2020, eg. For example, in confectionery, dips, soft drinks, etc. frequent consumption of fructose (fruit and sugar) chronic inflammatory processes in the gut and this is certainly the case for fast food and finished products is one of the causes of harm [15]

The first study in 2015 found that $0.1 \%$ of the daily ration of OPC in rats resulted in TNF- $\alpha$ after 12 weeks reduces the level of intestinal barrier permeability found that it reduces and supports the regeneration of the intestinal mucosa [16]. A new approach and paradigm shift is needed to be successful in treatment. a cause of IBD approach is essential. The main approach is the enteric nervous system, VSS, in addition to sympathetic loading, with loading of connective tissue together with nutrition, exercise, stress management, herbal medicine and should include selfhelp strategies.

Homeopathy, a natural remedy that has been used widely all over the world for 200 years system. It has been recognized by the World Health Organization (WHO) as the second largest treatment method used worldwide. Although it is the most popular form of treatment in India and South America, it is also used by over 30 million people in Europe and millions of other people around the world (17). Homoopathy treats the human as the mind, emotion and physical body. This is the breakdown in the system

\section{Conclusion}

Results in taking initial measures to alleviate chronic inflammatory bowel disease, namely:
Good stress management

Avoid things that may harm the intestinal flora or intestinal mucosa (unhealthy diet, alcohol, sweets, cigarettes, antibiotics, etc.)

\section{$\square$ Avoid plasticizers}

$\square$ Take vitamin $\mathrm{C}$ and vitamin $\mathrm{D}$ as needed

$\square$ Check for and correct nutrient deficiencies

$\checkmark$ Check for possible mercury contamination and remove mercury (or other heavy metals) if necessary; a tooth

Consult your physician (for amalgam fillings) and/or your GP.

\section{References}

1. Martins NB,(2004) Peppercorn MA. Inflammatory Bowel Disease. Am J Manag Care.;10:544-552

2. Ardizzone S, Bianchi Porro G.(2002) Inflammatory bowel disease: new insights into pathogenesis and treatment. Journal of Internal Medicine; 252: 475-496

3. Lobos EA, Sharon P, Stenson WF. Chemotactic activity in inflammatory bowel disease. Role of leukotriene B4. Dig Dis Sci 1987; 32:1380-1388.

4. Guan Q. (2019)“ A Comprehensive Review and Update on the Pathogenesis of Inflammatory Bowel Disease". Journal of Immunology Research; 2019: 1-16 ( Article ID 7247238)

5. Sgambato D, Miranda A, Ranaldo R, Federico A, Romano M. The Role of Stress in Inflammatory Bowel Diseases. Curr Pharm Des. 2017;23(27):3997-4002. doi:10.2174/1381612823666170228123357

6. Nazlikul, H(2016) Duygusal Beyin Bağırsak - Destek Yayınlar İstanbul

7. Nazlikul, H: Nöralterapi - Ders Kitab1 - Nobel Kitabevleri 2010 İstanbul S: 239-250

8. R H Straub et al;(2006)The role of the sympathetic nervous system in intestinal inflammation; Gut Nov; 55(11): 1640 1649

9. Benz AK,(2016) Optimale Vitamin D Zufuhr in der primären und sekundären Prävention bei Morbus Crohn, BachelorArbeit, Hochschule für angewandte Wissenschaften Hamburg, Fakultät Life Sciences, Department Ökotrophologie,

10. K Dunleavy, MB BCh BAO, R Ungaro, L Manning, J Novak, S Gold, J F Colombel, (2020) P144 Vitamin C deficiency in inflammatory bowel disease: the forgotten micronutrient, Journal of Crohn's and Colitis, Volume 14, Issue Supplement_1, January, Page S209

11. Animashaun A et al., The effect of zinc and vitamin $C$ supplementation on the immune status of patients with Crohn's disease, FULL LENGTH ARTICLE| VOLUME 9, ISSUE 3, P137-146, JUNE 01

12. Holt PR, Katz S, Kirshoff R. (2005)Curcumin therapy in inflammatory bowel disease: a pilot study. Dig Dis Sci. Nov;50(11):2191-3

13. Cui X, Jin Y, Hofseth AB, et al.(2010) Resveratrol suppresses colitis and colon cancer associated with colitis. Cancer Prev Res (Phila).;3(4):549-559. doi:10.1158/1940-6207.CAPR-09-0117

14. Bogner S, Lamprecht $M$ et al.(2015), Effects of zeolite supplementation on parameters of intestinal barrier integrity, inflammation, redoxbiology and performance in aerobically trained subjects, October, Journal of the International Society of Sports Nutrition 12(1):40, DOI: 10.1186/s12970- 015-0101$\mathrm{Z}$

15. David C. Montrose et al, (2020)Dietary Fructose Alters the Composition, Localization and Metabolism of Gut Microbiota 
in Association with Worsening Colitis, Cellular and Molecular Gastroenterology and Hepatology

16. Guan Yang et al.(2015), Favourable effects of grape seed extract on intestinal epithelial differentiation and barrier function in IL10-deficient mice, British Journal of Nutrition, Volume 114, Issue 1, 14 July , pp. 15-23

17. Postoğlu S. (2010)3.İleri yaş sempozyumu.Özet Kitabı.Ege geriatri Derneği.IZMİR..P.70
This work is licensed under Creative Commons Attribution 4.0 License

\section{To Submit Your Article Click Here: Submit Manuscript}

DOI: $10.31579 / 2641-5194 / 034$

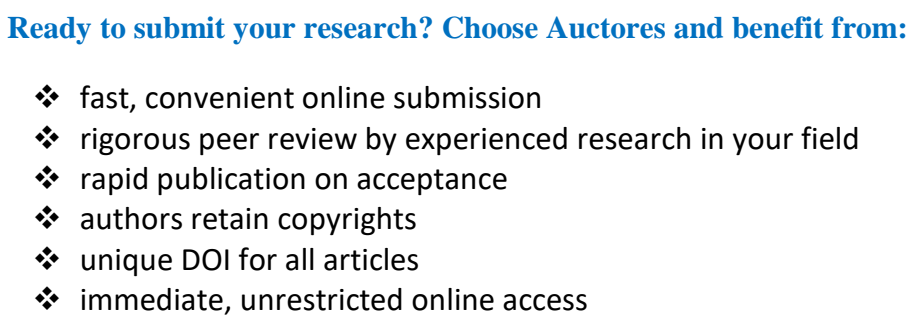

Ready to submit your research? Choose Auctores and benefit from:

* fast, convenient online submission

* rigorous peer review by experienced research in your field

* rapid publication on acceptance

* authors retain copyrights

* unique DOI for all articles

* immediate, unrestricted online access

At Auctores, research is always in progress.

Learn more www.auctoresonline.org/journals/gastroenterologypancreatology-and-hepatobilary-disorders 